\title{
From Goddess to Prophet: 2000 Years of Continuity on the Mountain of Aaron near Petra, Jordan ${ }^{1}$
}

\author{
ANTTI LAHELMA \& ZBIGNIEW T. FIEMA \\ University of Helsinki
}

The Lord said to Moses and Aaron at Mount Hor, on the border of the land of Edom [...] 'Take Aaron and Eleazar his son and bring them up to Mount Hor; and strip Aaron of his garments, and put them upon Eleazar his son; and Aaron shall be gathered to his people, and shall die there.' Moses did as the Lord commanded; and they went up Mount Hor in the sight of all the congregation [...] and Aaron died there on top of the mountain. (Num. 20: 23-28.)

\begin{abstract}
The Mountain of Aaron (Jabal Haroun) near the ancient city of Petra, Jordan, is the traditional burial place of the Old Testament prophet and a site considered sacred by the three world religions of Christianity, Judaism and Islam. Since 1997, a Finnish archaeological project has been investigating the mountain through the excavations of a Byzantine pilgrimage complex on its high plateau and an intensive survey of its surroundings. In the course of the excavations, it has become clear that the Byzantine structures were preceded by a monumental building, probably a temple of the Nabataean-Roman period. Moreover, already in the pre-Christian period a pilgrim route probably led from central Petra to Jabal Haroun. The article explores the history and archaeology of Jabal Haroun, which shows a remarkable degree of continuity and opens up the prospect that the local folk tradition may preserve elements of Nabataean religion. Using contemporary rituals and beliefs associated with the mountain as a reference point, we suggest that the pre-Christian 'deity of Jabal Haroun' can be identified as the Nabataean goddess al-'Uzza.
\end{abstract}

Keywords: Petra, Jordan, Nabataean, Byzantine, religion, al-'Uzza, Aaron

1 The research on the subject of this article has been carried out within the framework of the Research Centre 'Ancient and Medieval Greek Documents, Archives and Libraries', directed by Prof. Jaakko Frösén, which is part of the 'Centres of Excellence in Research' program of the Academy of Finland. We are grateful to Stephan Schmid (University of Basel), Jaakko Frösén and Päivi Miettunen (both of the University of Helsinki) for their critical comments. All errors of omission and interpretation are ours. 


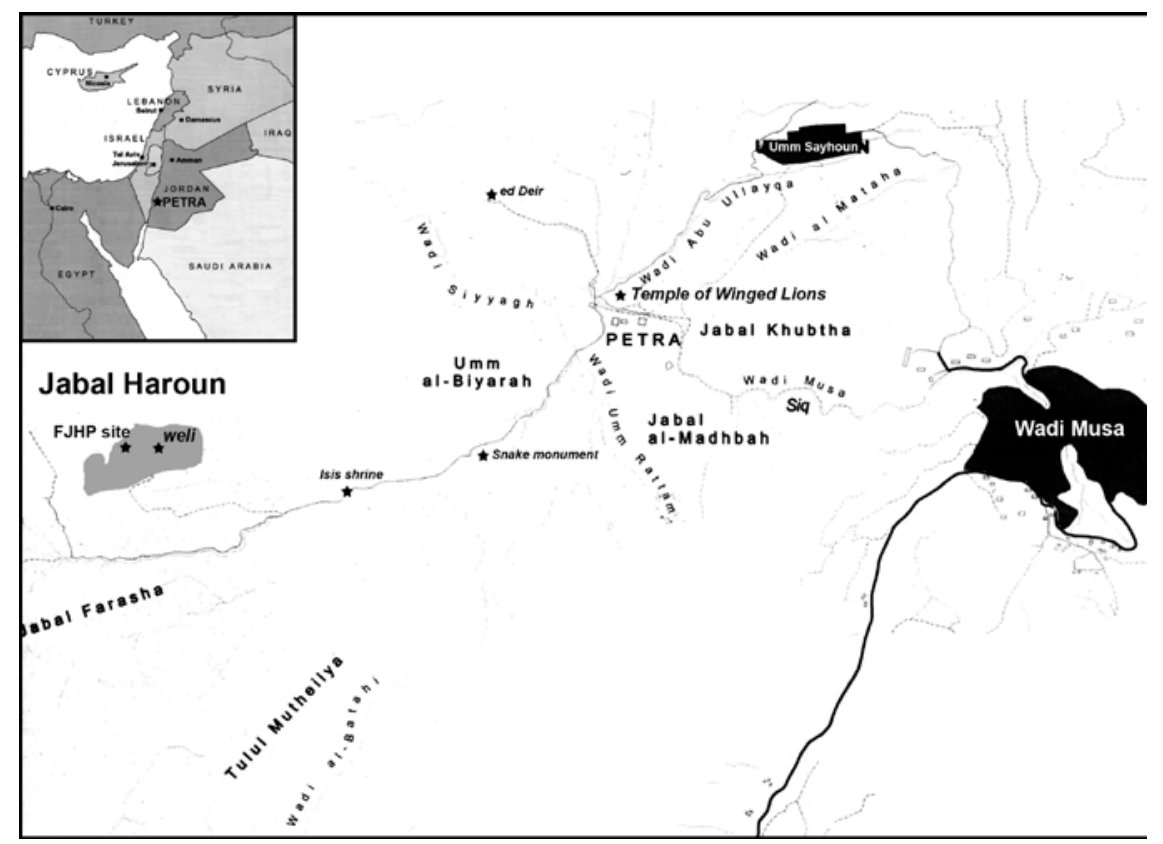

Figure 1. Location of Petra (left) and sites discussed in the text. Map: H. Junnilainen, K. Koistinen, P. Kouki \& A. Lahelma.

Ever since its rediscovery in 1812 by the Swiss explorer Johann Ludwig Burckhardt (1784-1817), the ruins of the ancient Nabataean city of Petra, located in the Jordanian desert ca. $200 \mathrm{~km}$ south of the capital Amman (Figure 1), have captured the Western imagination. ${ }^{2}$ The Nabataeans were a Semitic people, originally nomadic but later increasingly involved in trading and agriculture; they first appear in Greek historical sources in the fourth century все. For centuries, the kings of Nabataea successfully resisted Greek and Roman domination. Petra, the capital of the Nabataean Kingdom, conveniently located at the crossroads of ancient caravan routes between East and West, experienced conspicuous prosperity during the Late Hellenistic and Roman periods, as exemplified by the monumental edifices, such as rock-cut royal tombs and temples. Even after eventual Roman annexation in $106 \mathrm{CE}$, the city continued to flourish.

In the course of the Late Roman and Byzantine periods, however, a shift in trade routes led to Petra's gradual decline (Fiema 2003, 50). The city was

2 The most recent and comprehensive treatment of Petra and the Nabataean culture is by Schmid 2001. For an extensive bibliography on the subject, see Crawford 2003. The ancient sources concerning the Nabataeans are presented and discussed in Hackl et al. 2003. 


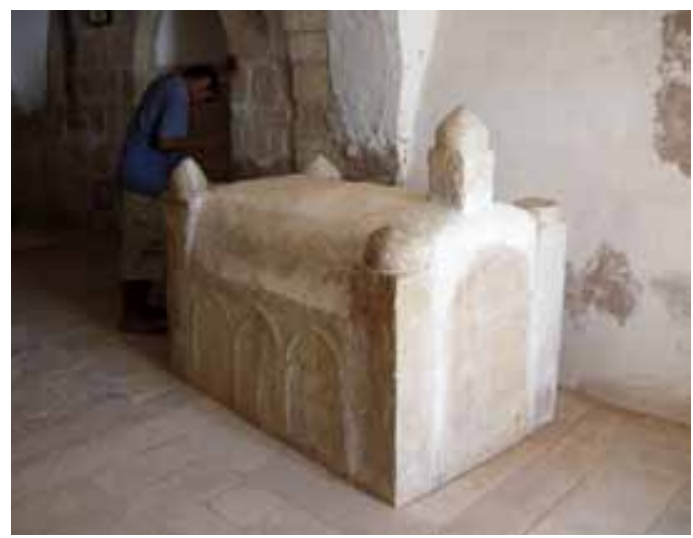

Figure 2. The cenotaph of Aaron (Haroun) inside the weli bears evidence of the long history of religious observance related to Aaron. Built partly of reused marble chancel screen posts from the Early Byzantine shrine, it is covered with Hebrew inscriptions left by Jewish pilgrims. The Arabic inscription in the central panel in the front records the building of the grave monument by Emir Seif-ed-Din in the fourteenth century CE. Photo: Anna Erving/FJHP.

struck, moreover, by a disastrous earthquake in $363 \mathrm{cE}$, which left many of the temples and other monumental structures permanently in ruins. The city was long thought to have been abandoned soon after the earthquake. The general scarcity in Byzantine sources of historical references to Petra has further added to the romantic mystery surrounding the Nabataeans. Recent archaeological excavations, however, have shown that Petra survived the disaster of 363, and was in fact able to recover to the extent that in the sixth century the city boasted several churches adorned with mosaics and marble decorations (e.g. Fiema et al. 2001; Fiema 2002, 2008).

Following Burckhardt's visit, the ruins of Petra were subsequently described by numerous Western scholars and travellers. Today they form a major tourist attraction as well as a UNESCO World Heritage site. In local tradition, however, the holy mountain of Jabal Haroun (the Mountain of Aaron), located ca. $5 \mathrm{~km}$ south-west of the centre of the city, has been far more significant than the ruins of a long-disappeared civilization. Indeed, Burckhardt himself travelled to Petra disguised as a Muslim pilgrim on his way to pay homage to the Prophet Haroun (Aaron), who according to tradition lies buried in a subterranean chamber under the fourteenth-century Muslim shrine (weli) ${ }^{3}$ built on the highest peak of the mountain (Figure 2).

Until recently, archaeological activity in Petra has been concentrated in the centre of the ancient city, where several large-scale excavation projects have taken place (e.g. Hammond 1996; Bignasca et al. 1996; Joukowsky 1998; Fiema et al. 2001; Schmid \& Kolb 2000; Ruben 2003). Apart from a

3 The word weli is a dialectal form of the Arab word wali, which means 'friend' and refers to both the saint and, in informal language, his shrine. The word maqām, meaning 'sacred site' or 'tomb of a saint', is also used by the locals. 
few brief reports concerning ruined structures on Jabal Haroun (Wiegand 1920, 136-145; Peterman \& Schick 1996), no substantial archaeological research had been conducted there until 1997, when the Finnish Jabal Haroun Project (FJHP) began its investigations. Headed by Professor Jaakko Frösén and funded by the Academy of Finland and the University of Helsinki, an international team of archaeologists, conservators, cartographers and other specialists has spent eight fieldwork seasons (between 1997 and 2007) excavating a ruined architectural complex (Figure 3) located on a large plateau below the summit of Jabal Haroun, and surveying its environs. The project is now nearing completion, and the first volume of its three-volume final publication has just been published (Fiema \& Frösén 2008). The volume contains major presentations on the figure of Aaron in ancient sources, as well as on the history of Jabal Haroun in past centuries (Frösén \& Miettunen 2008; Miettunen 2008). However, the data are still being analysed, and some of the observations made in this paper - especially with regard to the pre-Byzantine history and archaeology of Jabal Haroun - are therefore preliminary and tentative.

The purpose of this paper is to explore one significant aspect of the site, i.e. the literary, archaeological and ethnographic evidence for the long-term continuity of sacred significance of Jabal Haroun. The FJHP excavations as

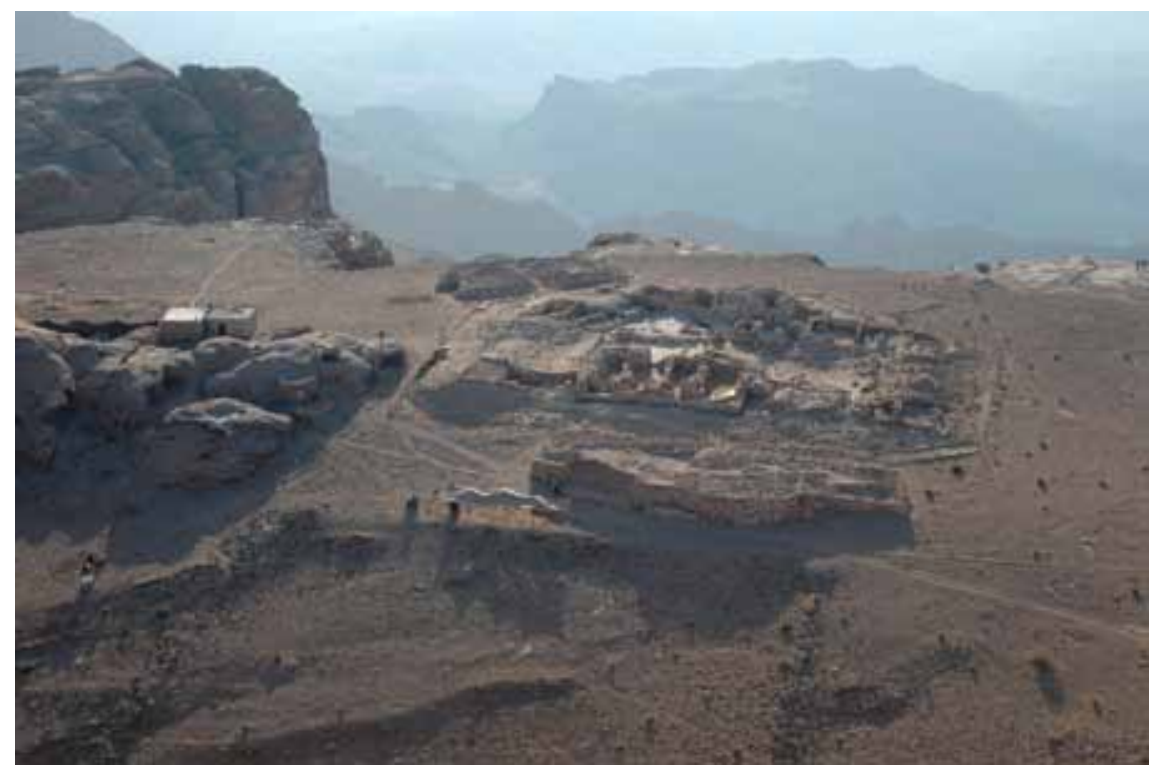

Figure 3. A view of the FJHP excavation site (in 2007) from the summit of the mountain. Photo: Matti Mustonen/FJHP. 
well as the intensive survey (Lavento et al. 2006) of its surrounding area, indicate that some aspects of religious tradition pertaining to the mountain extend from the Nabataean period to the present. Our findings may thus shed some new light on the Nabataean cult and religion, which due to the scarcity of ancient written sources remains poorly understood. The most recent study on the subject - John Healey's The Religion of the Nabataeans: A Conspectus (2001) - begins by stating the need for 'a certain creativity of thinking, [without which] all that we will be left with will be a recital of epigraphic and archaeological details' (Healey 2001, 2). While we acknowledge the speculative nature of the subject and the necessity of creative imagination in reconstructing Nabataean religion, we emphasise the unexplored potential of the archaeology of Nabataean religion, which can and does reach beyond 'details' that merely serve to illustrate the written records. We also wish to explore one particular strand of evidence so far largely ignored: the beliefs and practices of the contemporary populations of the Petra region, which - perhaps unexpectedly - appear to shed new light on the ancient past.

\section{A 'Direct Historical Approach' to the Cult of Jabal Haroun}

The investigations of the FJHP made it increasingly clear that the roots of the cult of Jabal Haroun lie in the Nabataean religion. It is significant that even though the city of Petra gradually became impoverished and was ultimately abandoned in the Early Islamic period, the mountain of Jabal Haroun remained in use as a holy site. Indeed, aside from the modern town of Wadi Mūsā (formerly known as the village of Elji), Jabal Haroun appears to be the only significant archaeological site in the entire Petra region where an apparent continuity from Nabataean to modern times is attested. This great historical trajectory, related to a site considered sacred by Judaism, Christianity and Islam, is remarkable in itself and worth recounting. On a different level, it enables a 'direct historical approach' to the archaeology of Jabal Haroun, based on aspects of local folklore and ritual in addition to historical sources.

The direct historical approach - a form of ethnographic analogy - was first elaborated in early twentieth-century North American archaeology (e.g. Steward 1942), where an abundance of ethnographic research combined with a lack of ancient historical sources made it natural to apply ethnographic material to the interpretation of archaeological finds. The theoretical basis of the direct historical approach lies in cultural continuity and transmis- 
sion. Quite simply, it is a method by which one works 'from the known to the unknown' (Steward 1942, 337) - from the ethnographic present towards prehistory. By emphasising the cultural and geographical links between past and present, the approach provides a rather straightforward solution to the problem of choosing the most relevant analogies for interpretation. Exactly how far back in time the approach can be extended is a difficult question, to which there is no clear-cut answer; but dramatic changes or breaks in the archaeological record may also indicate breaks in cultural transmission. There is also a need to exercise caution in the use of ethnography in interpreting archaeological remains, as the meanings of ritual practices and religious symbols may have undergone radical transformations in the course of time (Trigger 1995). Great care should thus be accorded to establishing (rather than assuming) the continuity of cultural forms.

This approach has enjoyed somewhat varying fortunes in different countries and subdisciplines of archaeology. A search for cult continuity has been persistently popular in Classical and Near Eastern archaeology, but in Central and North European archaeology the prehistoric past has often been viewed as completely disconnected from the present. ${ }^{4}$ In the United States, where the use of the direct historical approach had seemed so natural in the early twentieth century, the method fell into general disrepute with the New Archaeology of the 1960s (Lyman \& O'Brien 2001). This development is related to what may be seen as the 'downside' of the direct historical approach: its deceptive simplicity and obvious interpretative force can easily lead to misguided use. As Ann Stahl (1994, 181-2) points out, archaeologists who use the approach have tended to disregard change and stress the similarities between past and present, using the method rather freely to illustrate the less accessible aspects of past lifeways. This has caused some archaeologists (e.g. Fahlander 2004) to view the approach as essentially patronizing, branding indigenous cultures as 'cold' and stagnant, without social progress or flexibility. The critique of the direct historical approach is related to a wider scepticism concerning the use of analogy in archaeology (see Orme 1974; Wylie 1985), which has sometimes been erroneously perceived as somehow optional (e.g. Binford 1967). It is obvious, however, that if the goal of archaeology is to understand the past rather than merely describe it, the use of analogy is unavoidable. Critiques of the uses of

4 The main exception to this is the influential work of the early twentieth-century German archaeologist Gustaf Kossinna, whose notion of Siedlungsarchäologie is essentially a form of direct historical approach (Trigger 1989, 165). 
analogy in archaeology (including those pertaining to the direct historical approach) should thus be seen as critiques of flawed uses of analogy rather than of analogy as such.

Today, the direct historical approach is regaining popularity in both American and European archaeology (Lyman \& O'Brien 2001; Cunningham 2003), apparently because the New Archaeology failed to deliver on its promise of universal laws of human behaviour. Another possible reason is the growing interest in the archaeology of religion; as Bruce Trigger writes, the direct historical approach is the only technique available to archaeologists that allows detailed insight into culturally specific aspects of prehistoric ideologies and rituals (Trigger 1989, 342). True, direct continuation presupposes a causal order, which may be problematic; the development of religion usually involves multiple interacting causes. Ideally, relational analogies should be brought in to support direct historical ones. However, since religion is often culturally conservative and resistant to change, studying it may be particularly well suited to the direct historical approach. Its potential certainly needs to be explored in the study of Nabataean religion, where epigraphers and historians of religion are desperately short of useful data.

\section{Jabal Haroun in Written Sources}

In the Jewish, Christian and Muslim traditions, Mount Hor is specified as the place where Moses' brother Aaron died and was buried according to the Old Testament (Num. 20: 23-28, supra). ${ }^{5}$ The identification of Mount Hor is by no means clear, and Jabal Haroun, while a very strong candidate for this location, is only one of several potential places. It is noteworthy, however, that the tradition that places it near Petra is a very old one, going back at least to the writings of the first-century Jewish historian Flavius Josephus. As Josephus tells us in 'Jewish Antiquities' (Antiquitates Judaicae, written ca. $94 \mathrm{CE})$ :

[Moses] led his forces away through the desert and came to a place in Arabia which the Arabs have deemed their metropolis, formerly called Arce, to-day named Petra. There Aaron ascended a lofty mountain range that encloses the spot, Moses having revealed to him that he was about to die, and, in the sight of the whole army - for the ground was steep - he divested himself of his

5 For a detailed description of the sources see Frösén \& Miettunen 2008. 
high priestly robes and, after delivering them to Eleazar his son, upon whom by right of age the high priesthood descended, he died with the eyes of the multitude upon him. (Jewish Antiquities IV, 82-83; Josephus 1991, 516-7.)

Notably, Josephus feels confident in identifying the site as located near Petra, even though the location only barely fits the itinerary of the Israelites as described in the Old Testament (cf. Frösén \& Miettunen 2008, 5-6). Approximately two centuries later, Eusebius refers to Mount Hor in his Onomasticon (ca. 295), as 'the mountain on which Aaron died near the city of Petra, on which even until today is shown the rock (from which water) flowed by Moses' (Eusebius of Caesarea 2005, 165). In the following century, St. Jerome confirms 'Mount Or' as the mountain 'on which Aaron died, near the city of Petra, where even until today the stone is shown which Moses struck and gave water to the people' (ibid; translation according to Frösén \& Miettunen 2008, 11). It is worth noting that while these writers do not mention a tomb or sanctuary associated with the burial, they indicate that by this time tradition placed not only Aaron's death but also Moses' miraculous spring on the same mountain near Petra, and that the latter was being shown by the locals to pious visitors. This forms an interesting discrepancy with the Biblical account (Num. 20), certainly well known to both Eusebius and Jerome, in which it is very clear that these events took place in two different locations, Kadesh and Mount Hor.

In the sixth century we find the first references to a monastery near Petra. In $536 \mathrm{CE}$, two members of a 'Monastery of Aaron' are mentioned as attending the Church Councils in Constantinople and Jerusalem (Frösén \& Miettunen 2008, 12). The exact location of the monastery is not specified, but it was probably in Petra, as one of the Petra Papyri (inv. 6a, dated to 573) being studied by a Finnish team of papyrologists refers to 'the House of our Lord the Saint High-Priest Aaron' outside of the city of Petra (Frösén \& Fiema 1994; Gagos \& Frösén 1998, 477; Frösén 2001, 491; 2004, 142). ${ }^{6}$

Despite the Islamic conquest of the region in the early seventh century, a Christian presence seems to persist for several centuries at Jabal Haroun. The Vita of St. Stephen the Sabaite mentions a 'Mār Hārūn' - probably Jabal Haroun - as a holy site visited by Christian monks of the mid-eighth century (Leontios of Damascus 16.2, 1991, 96-7). The site is mentioned again

6 With two volumes published so far (Frösén et al. 2002; Arjava et al. 2007), the scientific publication of the papyri is still underway. Papyrus inv. 6a will be published in a forthcoming volume of the Petra Papyri series. 
around 955/956 by the historian Al-Mas' $\bar{u} d \overline{1}$, the 'Herodotus of the Arabs', who writes of Jabal Haroun as a Christian holy mountain in the possession of the Melkites (al-Mas' ùdī 1894, 143-4). Two centuries later, the mountain reappears in the accounts of the Crusades. The Crusader leader Baldwin, just before he became king of the Latin Kingdom, visited Jabal Haroun in 1100. His chaplain, Fulcher of Chartres (b. 1059), describes the visit: 'Furthermore we found at the top of the mountain the Monastery of St Aaron where Moses and Aaron were wont to speak with God. We rejoiced very much to behold a place so holy and to us unknown.' (Fulcher of Chartres 1913, 381; translation according to Frösén \& Miettunen 2008, 13.)

This account proves that the monastery, in whatever form (Fiema 2008), was still in existence in the twelfth century. Magister Thetmarus, who visited Petra in 1217 during a truce between the Christians and the Arabs following the battle of Hattin, mentioned Jabal Haroun and wrote that a church on its summit was inhabited only by two Greek Christian monks (Magister Thetmar 1983, 272; cf. Frösén \& Miettunen 2008, 14). However, he did not visit the summit but merely reported what he had heard. Quite soon after his account, the Christian history of Jabal Haroun seems to have come to an end.

Islamic records of Jabal Haroun are few in number, suggesting that the site was mostly of local importance. In 1276, the Mameluke Sultan Baybars traveled through Petra and ascended the slopes of the mountain on which was 'the tomb of Aaron, Prophet of God, the Brother of Moses, Son of 'Umran' (Zayadine 1985, 173). The account of Baybars' journey does not mention any specific religious structures on the site. The major event in the Islamic history of the mountain was the construction of the Islamic shrine (weli) in the fourteenth century. The site is mentioned, once more, by the Arab geographer Yaqūt in the 15th century (al-Salameen \& al-Falahat 2007, 259), but after this all mentions of Jabal Haroun become exceedingly scarce. A few Jewish writers, including Rabbi Jacob (writing between 1238-1244), and an anonymous author who visited the site in 1537, refer to Jabal Haroun as a site of pilgrimage (Peterman \& Schick 1996, 478). Thereafter Jabal Haroun more or less disappears from the historical sources until its 'rediscovery', for the West, by Johann Burckhardt in 1812.

In addition to these written sources, some inscriptions found near the site clearly indicate that the site was frequented in the Islamic period (alSalameen \& al-Falahat 2007). The oldest inscription, a short plea to Allah, is fragmentary and contains no date, but is according to Zeyad al-Salameen and Hani al-Falahat paleographically datable to the eighth or ninth century. A second, longer inscription refers to the mountain as a 'blessed and hon- 
oured place' and asks for Allah's forgiveness for all Muslims. It includes the date $690 \mathrm{AH} / 1291 \mathrm{CE}$, thus predating the construction of the weli. Other inscriptions, probably dated to the Ottoman period (including one with the date $1019 \mathrm{AH} / 1610 \mathrm{CE}$ ), complete the evidence for the sanctity of the site throughout the Islamic period.

Three major events associated with the history of Jabal Haroun took place in the twentieth century. The German explorations at the summit of the mountain revealed the remains of a Byzantine Christian church beneath the Islamic weli, probably also associated with the cult of Aaron (Wiegand 1920, 136-45). A large quadrangular ruin, located on the high plateau of Jabal Haroun, ca. $70 \mathrm{~m}$ below the peak with the Islamic shrine, was visited in 1991 by Peterman and Schick (1996), who concluded that these ruins should be identified with a Byzantine monastery of St. Aaron mentioned in Byzantine sources. Finally, the information derived from the Petra Papyri (supra), combined with the religious tradition associated with Jabal Haroun and with the results of the early explorations in the area, would strongly suggest that the architectural remains on the high plateau of the mountain, which are the focus of the FJHP excavations, should indeed be identified as the Byzantine Monastery of Saint Aaron. ${ }^{7}$

\section{From the Western Building to... the Western Building - The Archaeologi- cal Sequence at Jabal Haroun}

Like the written sources, the archaeological record of Jabal Haroun provides evidence for a religious tradition which, although 'reinvented' over the course of centuries, has continued for at least the past two thousand years. The focus of the FJHP investigations is a ruined building complex on the high plateau, just below the summit, measuring ca. $62.9 \mathrm{~m} \mathrm{~N}-\mathrm{S} \times 46.7$ $\mathrm{m}$ E-W. ${ }^{8}$ Although most of the currently visible structures in their extant form belong to the Byzantine monastery dedicated to St. Aaron which existed roughly between the later fifth and the eighth/ninth century, the site contains more Nabataean remains than initially assumed (Figure 4). A brief description of the site is therefore followed by an account of the spatial and temporal changes which occurred from the Nabataean until the Early Islamic periods.

7 See also Lindner 2003, 177-204 for a recent description of Jabal Haroun and the way leading to the mountain from Petra.

8 For references to all reports as of now published concerning the FJHP see Fiema \& Frösén 2008. 
Figure 4. Simplified plan of the excavation site, showing the outlines of the Nabataean Western Building and the temenos in grey and the Byzantine church, chapel and pilgrim hostel in black. Most installations and some dividing walls have been removed for increased clarity. Map drawn by A. Lahelma, based on the top plan of the site created by Vesa Putkonen and Katri Koistinen.

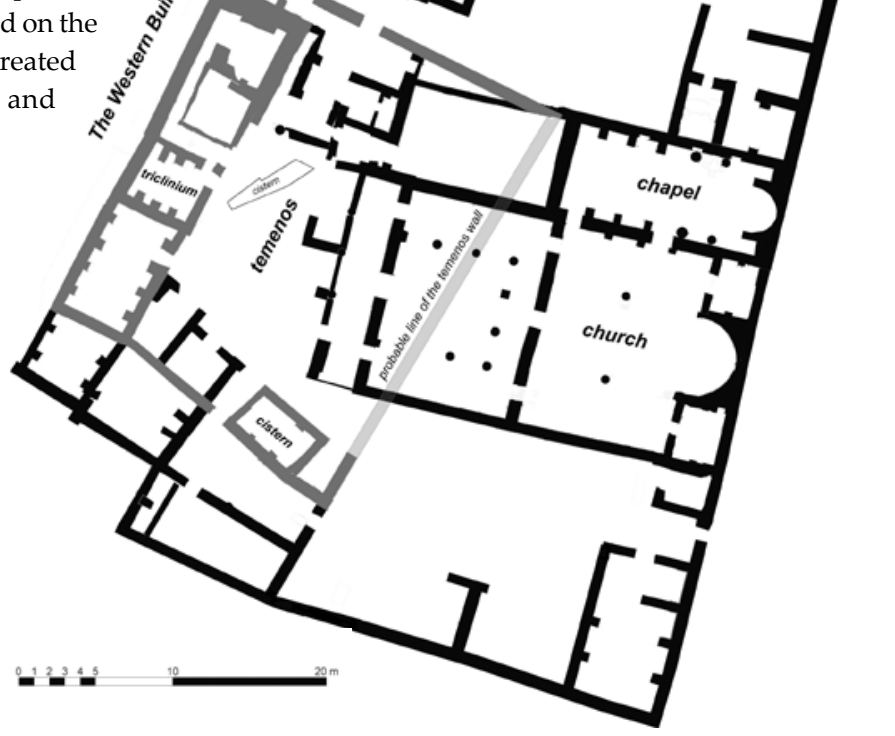

The site in general can be divided into four main components or wings, situated around three courts (Figure 4). The east-central location is occupied by the church and the chapel. The former is preceded by an entrance porch located next to the central court; the court has a natural fissure or depression in the bedrock, which apparently served as a cistern in the Byzantine period. Directly west of the cistern, there is the long, multi-roomed Western Building. South and southeast of the central court lies a wing of rooms forming the southernmost part of the complex. Of special interest are two large rooms spanned by double arches. This area of the site features a particularly complex architectural history, which must have already begun in Nabataean times. In front of these rooms, a rock-cut water cistern, of Nabataean date, has been partially excavated. North of the chapel lies a large, U-shaped wing of 16 rooms located around the northern court, which may be interpreted as the accommodation of the monastic community or a hostel. 


\section{The Nabataean Cultic Complex}

As mentioned above, the discrete components of the complex feature different dates and some clearly precede the Byzantine monastery. This so-called Western Building was built around a cistern formed by a natural cavity in the bedrock. At present the analysis of the material excavated in the Western Building is still underway and the precise dating and function of the structure are uncertain, but a Nabataean date is suggested by the building technique and by finds of Nabataean pottery of the first and second centuries CE. The two northernmost rooms, which together with a large stairway form the core of the Western Building, might have originally been a Nabataean shrine or small temple standing in front of the bedrock fissure-cum-cistern (Figure 5). The ashlars used are truly massive in size, and fragments of cornices and other decorative elements, found in reused positions in the Byzantine structures, suggest that the shrine was of a monumental design and that the exterior of the building was also decorated. The results of the 2007 FJHP excavation now permit a tentative reconstruction of what would have been a Nabataean sacral complex. It must have consisted of a shrine located in the Western Building, of the Nabataean rock-cut cistern, of some rooms in the southwestern part of the site, and of the courtyard, possibly featuring a colonnade. All of these were enclosed in a quadrangular design (probably a sacred enclosure or temenos), and clearly centred upon the rock fissure in front of the Western Building. All the structures in this early complex show a clearly different orientation (NE-SW) from that of the succeeding Byzantine monastery $(\mathrm{N}-\mathrm{S})$.

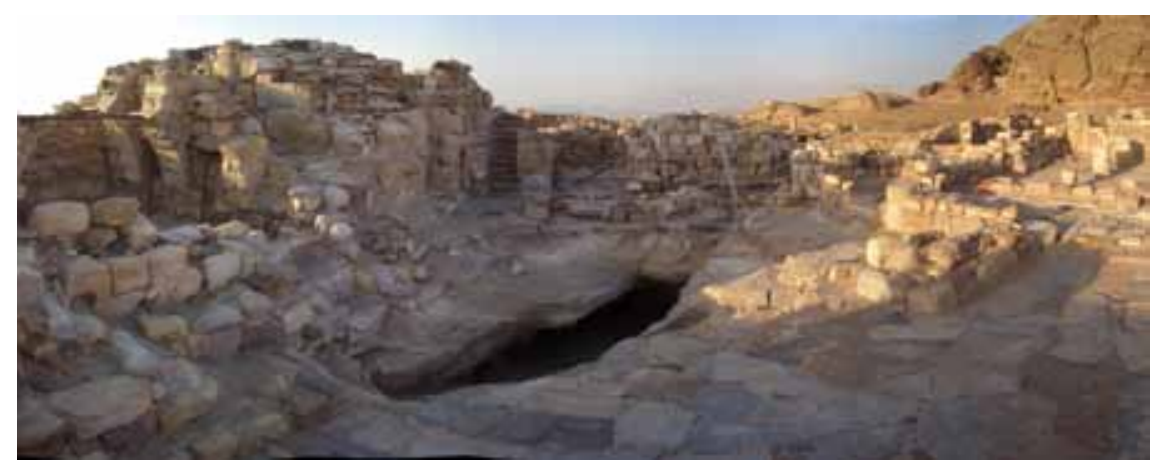

Figure 5. A view of the natural fissure-cum-cistern, which forms the focal point of both the Nabataean temple and the Byzantine ecclesiastic complex. The Western Building is on the left side of the image, the church and the summit of Jabal Haroun are on the right. Photo: Antti Lahelma/FJHP. 
One should note the presence of the third room, directly south of the Western Building, built in a different form but most probably added to the Western Building already in the pre-Byzantine times. It is a room with three arches spanning the interior, also featuring three wide benches along the walls. This design clearly resembles a triclinium, i.e. a banquet room, characteristic of the domestic architecture of the Classical period. Triclinia are also known in Nabataean architecture; they are typically associated with ancestor cults and tombs, as a site where ritual and commemorative meals were held by family or a religious fraternity, but also sometimes occurred in temples (Healey 2001, 165-9). As this triclinium is structurally a component of the Western Building, the entire design might at least structurally be compared to the Nabataean temple complex at Khirbat at-Tannūr (McKenzie et al. 2002). That complex, located ca. $70 \mathrm{~km}$ north of Petra, features a small rectangular temple edifice, with a row of steps on the exterior of the building leading to an altar platform on the roof. A rectangular courtyard in front of the temple is enclosed by a colonnaded temenos wall, and there are three triclinia within its walls. The layout of the Khirbat at-Tannūr temple is more regular and its façades far more sumptuously decorated than those of the Jabal Haroun building, but the similarities are obvious. Notably, like the Nabataean complex at Jabal Haroun, the sanctuary is located on the peak of a mountain (Jabal at-Tannūr).

The Western Building and other structures are not the only evidence for Nabataean activity at Jabal Haroun. Nabataean pottery was found both at the FJHP site and on the summit of the mountain, suggesting that in addition to the monastery, the weli and the Christian shrine underneath may have been preceded by Nabataean cultic installations. At the foot of the summit, where a path begins to ascend towards the weli, there is a large (ca. $20 \times 4 \mathrm{~m}$ ) cistern, spanned by a row of fifteen arches supporting its roof. Its dating is uncertain but its architecture suggests the Nabataean period. A small Nabataean cultic site (FJHP site 4), featuring a rock-cut niche and a semi-circular enclosure, is found close to the cistern (Frösén et al. 1998, 493). In its vicinity, abandoned and worn rock-cut staircases - again, probably Nabataean - ascend towards the summit. A second cistern (FJHP site 182), accompanied by elaborate rock-cut water channels, lies at a distance of ca. $100 \mathrm{~m}$ in the cliffs to the south of the ruins.

In this context, the postulated Nabataean cultic centre at Jabal Haroun, and especially the Nabataean 'infrastructure' located around the site, bear some resemblance to other Nabataean 'high places' of sacrifice, which are among the most characteristic archaeological remains associated with $\mathrm{Na}$ - 
bataean religion (Healey 2001, 48-9). The best known high place in Petra, $\mathrm{Zibb}$ 'Atuf, is located on a ridge ca. $200 \mathrm{~m}$ above the city. It consists of an altar (size $3 \mathrm{~m} \times 2 \mathrm{~m}$ ), preceded by two steps, on which a 'block idol' (betyl) may have stood. Rock-cut reservoirs, channels and basins indicate that both the presence of water and the occurrence of blood sacrifices may have been significant elements of the ritual. Jabal Haroun clearly invites comparison with this and other Nabataean high places. Although Jabal Haroun is rarely mentioned in treatises on Nabataean religion or interpreted as a high place, the idea is not new. George Robinson (1908) suggested already at the beginning of the twentieth century that Jabal Haroun, towards which a number of other high places appear to be oriented, may have been the chief mountain sanctuary of the city. Stewart Crawford $(1930,296)$ echoed the same idea in his survey of the high places of Petra, maintaining that the smaller altars were directed towards the larger ones (thus 'borrowing' their sanctity), and that the focus of the larger altars was Jabal Haroun. With a distinctively shaped peak rising $1330 \mathrm{~m}$ above sea level Jabal Haroun is indeed the highest peak in the area, easily attracting attention and the imagination. Like the high place of Zibb 'Atuf, the Nabataean 'Western Building' is associated with water reservoirs and a triclinium.

\section{The Byzantine Monastery}

At any rate, possibly as a result of the earthquake of $363 \mathrm{CE}$, the Western Building and presumably the entire Nabataean sacral complex seems to have been severely damaged and temporarily abandoned. When the Byzantine monastery was built in the late fifth century, some of the now apparently rebuilt structures of the original Nabataean complex were incorporated into the monastery as its western part, but the function of these structures was obviously completely different.

The major Byzantine structures at the site - the church and the chapel - exhibit several phases of occupation interspersed by episodes of destruction and remodelling. ${ }^{9}$ Generally, only a few monastic churches in the region can be compared with the Jabal Haroun church, and most of these are memorial churches, either commemorating a specific Biblical event or person and/or clearly associated with pilgrimages. ${ }^{10}$ This also implies that,

9 For a full description of the various phases of the church and the chapel see Mikkola et al. 2008.

10 For the memorial churches see the discussion in Hirschfeld 1992, 55-6, 130. 
despite its location in a relatively remote area, the Jabal Haroun church was not intended to be used only by the monastic community. A large tripartite, monoapsidal basilica associated with a chapel with a baptismal font would have provided much more space than required for the liturgical services for such a community. Taken together with the traditional association with a well-known Biblical figure, the size and appearance of the ecclesiastical structures at Jabal Haroun thus strongly support the idea of their memorial character and thereby an association with pilgrim traffic.

With regard to the memorial/pilgrimage-oriented character at the site in the Byzantine period, the presence of sixteen rooms arranged around the northern court is meaningful. This arrangement recalls a typical Near Eastern caravanserai. It is highly relevant that these rooms appear to be relatively large in size: almost twice the size of known cells in some Judaean Desert coenobia (Hirschfeld 1992, 176-7). While some of these rooms might have served as monks' cells, they could thus also be interpreted as pilgrim hostel rooms.

\section{The Site in the Early Islamic Period}

Following one of the several destructive episodes in the history of the site, the church appears to have been ecclesiastically abandoned by the ninth century. The adjoining chapel continued as an ecclesiastical edifice for some time, although presumably not later than the Crusader period. The evidence of human presence on the mountain in the Middle Ages is found in surface finds of so-called Ayyubid-Mamluk pottery or handmade geometrically painted ware, generally dated to the late twelfth to fifteenth century (Walmsley 2001, 544-53). Pottery of this type has been found in abundance in the northeastern part of the summit of Jabal Haroun. This pottery is probably associated with the monks mentioned by medieval chroniclers, although it is not unlikely that pilgrims might occasionally have brought some food in pots as well. Characteristically, the sherds come from the summit rather than the plateau. From a stratigraphic point of view, however, the Western Building, and probably the triclinium, appear to have been used until the very end of occupation at the monastery, sometime during the Crusader/ Ayyubid/Mamluk period. Any permanent Christian presence must have ended at the latest when the weli was built in the fourteenth century, and the remains of the Christian chapel on its site were dismantled. 


\section{Jabal Haroun in the Local Ethnographic Record}

Given the historical and archaeological evidence for long-term continuity, the possibility that the local ethnographic record may preserve elements of the pre-Islamic and even pre-Christian cult of the mountain has to be seriously considered. The ethnographic record - evidence of pilgrimages, ceremonies and sacrifices to Prophet Haroun - has thus far been largely ignored in the assessment of the specific cultic importance of the mountain, and it needs to be briefly addressed here. In all probability, animal sacrifice has been associated with the cult of Jabal Haroun since time immemorial. The first written record of the practice, however, dates back only to 1812, to Burckhardt $(2007,410)$, who offered a goat to the prophet at the foot of Jabal Haroun:

While I was in the act of slaying the animal, my guide exclaimed aloud, 'O Haroun, look upon us! It is for you we slaughter this victim. O Haroun, protect us and forgive us! O Haroun, be content with our good intentions, for it is but a lean goat! O Haroun, smooth our paths; and praise be to the Lord of all creatures!' This he repeated several times, after which he covered the blood that had fallen on the ground with a heap of stones; we then dressed the best part of the flesh for our supper, as expeditiously as possible, for the guide was afraid of the fire being seen, and of its attracting hither some robbers.

Burckhardt also reports that there were three copper vessels housed in a room adjoining the tomb of Haroun, to be used by those who performed the sacrifice at the top of the mountain. The largest of the kettles, according to him, was used for boiling camel meat (Burckhardt 2007, 410). However, this is based on hearsay, as he in fact never reached the summit of the mountain. We are not aware of camels being sacrificed to Haroun in the recent past (camels being a prestigious commodity), but goat sacrifice is very much part of a living tradition (Figure 6).

Päivi Miettunen $(2004,2008)$ has recently presented a detailed discussion of the folklore and traditions relating to Jabal Haroun. According to her, the main reason for the autumnal pilgrimage (ziyara) to Jabal Haroun was to sacrifice a goat, and in doing so to pray to Haroun for rain. Local folklore abounds in tales of miraculous rains that fall down immediately after the pilgrimage. However, if the rains did not start in time or were slight, a ritual procession, the Amm al-gheth or 'Mother of Rain', was organized by the women of the community. The 'Mother of Rain' was a crude female doll, 


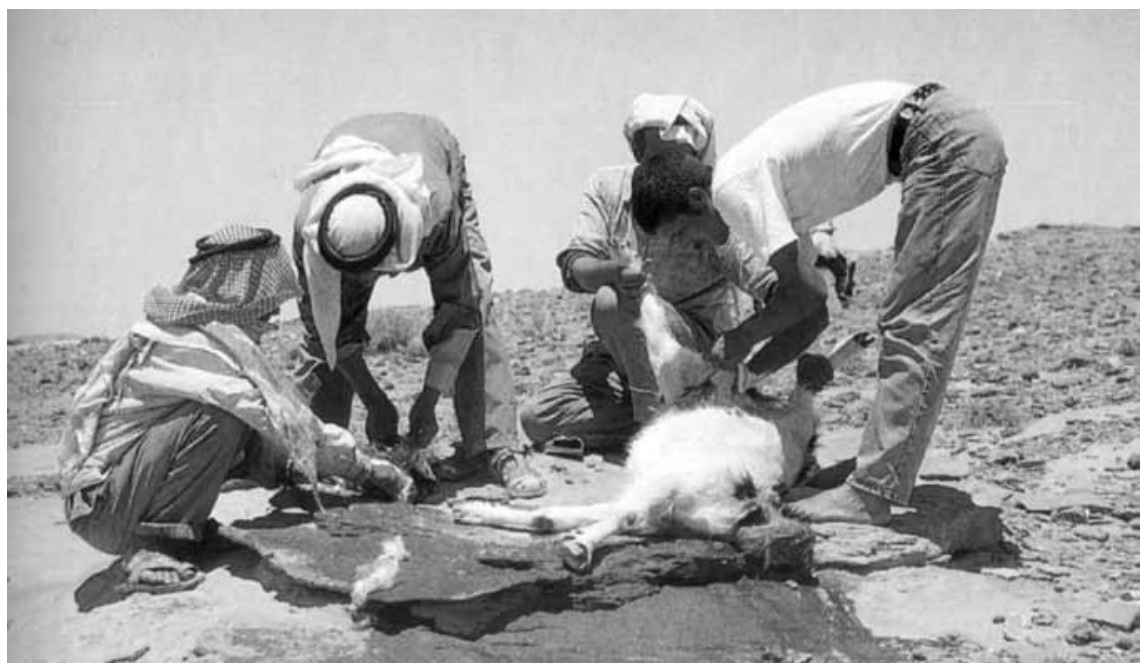

Figure 6. Goat sacrifice on top of the ruins of the monastery in the beginning of the first FJHP field season (1998). Photo: Nina Heiska/FJHP.

carried by a virgin in a procession of women that went around a village or camp, visiting local shrines and singing special songs for the ritual (Figure 7). The ritual as such was not limited to the region of Petra or Wadi Mūsā, but in the vicinity of Petra it was associated with the cult of Haroun. Local women traditionally did not climb all the way up the mountain, but gathered at a place from which the mountain could be seen. Today the association

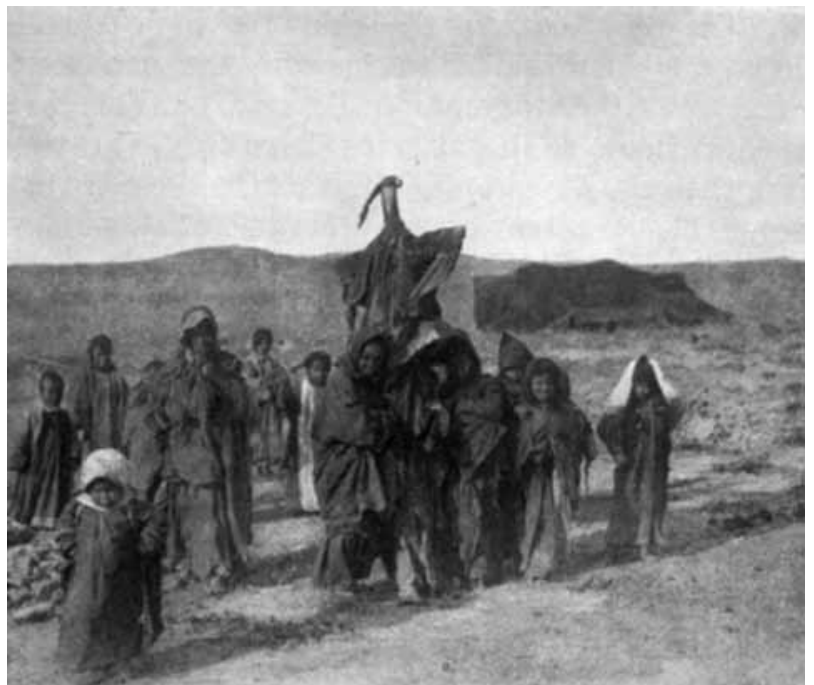

Figure 7. An earlytwentieth-century procession of the 'Rain Mother' among the Rwala Bedouin in the Syrian Desert. From Musil (1928, 13). 
with Prophet Haroun is more pronounced and the songs for Amm al-ghèth are sung during the autumn pilgrimage to Jabal Haroun, even within the shrine itself. Some of the songs are addressed directly to Allah, while others are prayers to the Mother of Rain, such as the following:

\begin{tabular}{|c|c|}
\hline & \\
\hline wet & Balli zrā'īna-l-nāym \\
\hline Mother of the rain [of the slopes?] & Yā-amm al-ghèth yā hadrij \\
\hline $\begin{array}{l}\text { the (her) floods run in their courses. } \\
\text { Miettunen } 2008,42 . \text {. }\end{array}$ & Khalli siyālha yidrij \\
\hline
\end{tabular}

Although the Amm al-ghêth prayers are still sung, the identity of the 'Mother of Rain' was unknown to the locals already in the early twentieth century. Miettunen $(2008,42)$ suggests that the prayers and the ritual process may be remnants of an ancient, local ritual, as ritual processions where effigies of deities were carried were common in the ancient Near East. Haroun's association with agriculture - rather surprising in view of the Biblical Aaron - is also implied in the tradition, still attested in the 1920s, in which the saden (custodians of the weli) of Jabal Haroun would go to the local peasants and collect a share of the grain and olive oil for Haroun. Al-Salameen and al-Falahat $(2007,259)$ view this as a continuation of ancient pagan and Jewish custom.

In many of the local legends concerning Haroun, he is, curiously enough, said to dislike camels, an animal of paramount importance to the Bedouin. Two local Bedouin, Ibrāhīm 'Amārīn and Abū Šāher, explained to Miettunen in 2002 that Haroun refused to be buried in the place where he died, as it was an oasis where passing camel caravans used to stop and rest (Frösén \& Miettunen 2008, 10). Instead, he requested Mūsā (Moses) to bury him up on a mountain, where no camel would climb and disturb him. Another reason for choosing Jabal Haroun as his tomb was that no other mountain could endure the weight of the prophet, but all shook heavily and crumbled. Only Jabal Haroun stood firm, implying the extraordinary (sacred) nature of the mountain. Haroun's aversion towards camels is an intriguing detail; one wonders if it might not be related to his association with agriculture and fertility, thus reflecting the traditional animosity between nomadic pastoralists and farmers, but also most probably the survival of some other, much more ancient tradition associated with Jabal Haroun. 


\section{The Nabataean Cult of Jabal Haroun: a Hypothesis}

With the identification of the pre-Byzantine remains at Jabal Haroun as a Nabataean cultic complex, one question which remains to be addressed here relates to the specifics of the cult at that location. At Petra, high places are typically approached by clearly defined processional ways (Healey 2001, 72). Such a way may also have led to Jabal Haroun. There is a small Nabataean shrine devoted to Isis at Wadi Abū Ollēqah (FJHP site 166, cf. Parr 1962; Lindner 2003, 179), featuring a female anthropomorphic figure with draped clothing (including an 'Isis knot') carved on a rock cliff (Figure 8). The figure is turned towards Jabal Haroun and has been placed at a spot where a small waterfall brings water to the wadi in the rainy season. A small temple or peristyle in front of the niche was noted by Manfred Lindner (1997, 286-92), who connected the site with a pilgrim way from central Petra to Jabal Haroun. There is some evidence suggesting that pilgrimages were an important part of Nabataean religion (El-Khouri 2007); even today, a pilgrim route, the Darb al-Nabī Haroun ('the road of the Prophet Aaron') from Wadi Mūsā to Jabal Haroun (Miettunen 2008, 39-40) runs past the shrine. As Lindner $(1997,291-2)$ suggests, it is likely that Nabataean pilgrims to the mountain prayed and sacrificed to the goddess here before they did the same

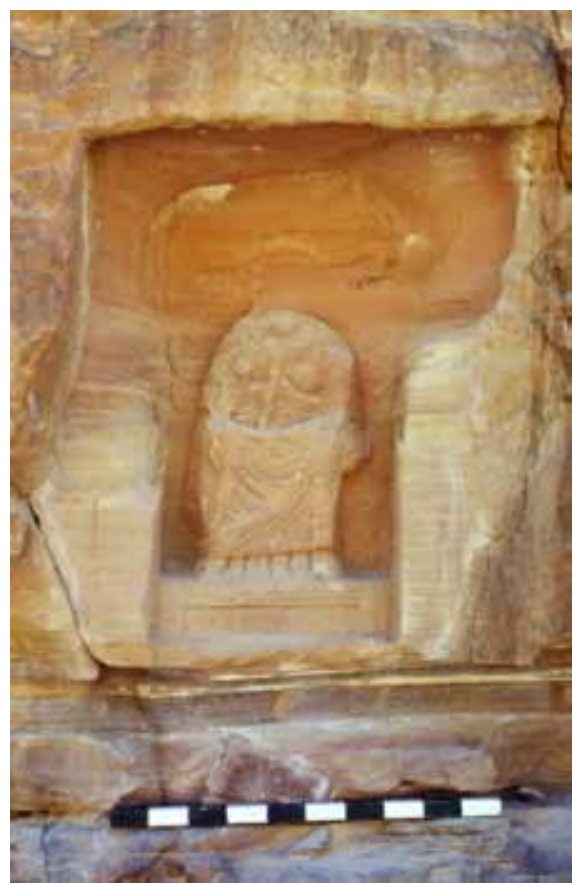

on the mountaintop. This theory is supported by a second niche at Wadi es-Siyyagh, which features an image of Isis that appears to sit on a stylized mountaintop (Donner 1995, 12-3).

Notably, the association of the mountain in recent folklore with crop fertility and the mysterious 'Mother of Rain', as discussed above, would fit well with the interpretation featuring Isis as the 'deity of Jabal Haroun'. In Egyptian mythology, Isis represents the fertile banks of the River Nile, which in

Figure 8. The 'Isis niche' of Wadi Abū Ollēqah, located along the road from central Petra to Jabal Haroun. Scale 1 meter. Photo: Paula Kouki/FJHP. 
turn was formed from the tears of the goddess falling from the heavens as she mourned for her husband Osiris (Witt 1971, 14-5, 19). She has many other aspects, especially in later Hellenistic religion, but her role in agriculture and fertility is pronounced. The cult of Isis was characterized by large and colourful ritual processions (pompae), in which a statue or symbol of the goddess was carried - recalling the Amm al-ghêth (Witt 1971, 93-4, 165-84). Interestingly, the Isis sanctuaries of the Roman world almost without exception included a 'crypt' as part of their design (e.g. Wild 1981, appendix 2). One wonders if the crypt of Aaron, located under the weli, might thus derive already from the Nabataean-Roman period. Perhaps it was originally associated with Isis, and was only later - with increasing Christian influence -'re-invented' as belonging to Aaron. Such identifications (or inventiones) of pagan sacred sites as the tombs of Biblical characters or Christian martyrs - typically involving a dream, in which the location of the tomb was revealed to a monk, and an 'excavation', in which the existence of a burial was confirmed - were certainly commonplace in Late Antiquity (di Segni 2007). ${ }^{11}$ Inventiones seem to have been especially common between the late fourth and the mid-fifth century, and were widespread to the point of arousing concern among some Christian writers that the Church was in a danger of losing its credibility among contemporaries (Di Segni 2007, 381-2).

Although the influence of Isis on religion in Petra was considerable (see Healey 2001, 137-40), one needs to identify the native strand of that cult and the religio-cultural assimilation of the foreign deity to the native one. There seems to be a common consensus that in many cases the images and inscriptions related to 'Isis' should be identified at Petra with al-'Uzza ('The All-Powerful'), a pre-Islamic Arabian deity who apparently was the supreme goddess of the Nabataeans (Healey 2001, 114-9). Her nature is unclear (Macdonald \& Nehmé 2000), and her cult at Petra may moreover have differed significantly from the al-'Uzza worshipped by other Arab populations. The Isiac attributes suggest that at Petra she was, perhaps above all a goddess of agriculture and fertility. She appears on the façade of the el-Khazneh - the most famous monument of Petra - where an eroded relief figure of a goddess holding a cornucopia in her left arm has been identified as al-'Uzza embodying the attributes of Tyche and Isis (Lindner 1997, 116). Her main

11 A story told by the Bedouin of Petra in the early twentieth century concerning the discovery of the Prophet's body appears to follow the characteristic formula of inventiones: shining lights from Jabal Haroun signalled the burial place to the local inhabitants, who proceeded to dig into the mountain until they found the dead saint, who was then ceremoniously buried in a marble coffin (Musil 1907, 115-6). 
sanctuary in Petra may have been the 'Temple of Winged Lions' excavated by Phillip Hammond (1996), where Isiac iconography and architectural features - including a crypt - are well attested. The temple was destroyed in the earthquake of 363 and never rebuilt, but a Church dedicated to Virgin Mary was built next to it in the Byzantine period..$^{12}$ There may be an element of cult continuity here as well; it is well known that the Virgin Mary took over many features of Isis in Late Antiquity (e.g. Witt 1971, chapter 10). It may be noted, too, that the Church Father Epiphanius (ca. 310-402) was distressed by what he perceived as a deceitful mimicry of Christian faith at Petra, in his reference to a temple in Petra which was dedicated to a virgin goddess - possibly Isis/al-'Uzza - who gave birth to the god Dushares (Epiphanius 1990, 51). ${ }^{13}$

The goddess Isis/Al-'Uzza, as she was worshipped by the Nabataeans, appears to have been closely linked with springs, water reservoirs and grain. Here we have to emphasize the presence, on the high plateau of Jabal Haroun, of the natural fissure-cum-cistern. The fissure is clearly the focal point of the Nabataean Western Building and its temenos, and therefore may also have been a significant element in the pre-Christian cult. The fact that (unlike most Nabataean cisterns) it is at least outwardly unmodified seems significant. The presence of water on top of an arid mountain may have been perceived by the Nabataeans as miraculous, and the fissure may have been thought of as a sacred spring. A second, possibly related structure was found in the FJHP survey at the foot of the path leading up to the mountain (Frösén et al. 2000, 420-1). The structure is probably of Nabataean date and features a masonry-built 'well' (which could not have kept water), a channel, and a surrounding semicircular wall. Small-scale excavations conducted at the site failed to clarify the function of these features, but they seem to be related to the processing of a liquid, which is surprising given the arid surroundings. Perhaps the structure is related to some form of ritual display of water luxury - a symbolic spring? - which

12 The church is the main ecclesiastic edifice of Byzantine Petra and was excavated by an American team in the 1990s (Fiema et al. 2001). The identification of the ruins with a church dedicated to Virgin Mary is based on thus far unpublished papyri (inv. 6a, 49 and 82.5) found in the church (see Gagos \& Frösén 1998, 477; Frösén 2001, 491; 2004, 142).

13 Like the Virgin Mary, Isis was both 'Mother of the God' and 'the Great Virgin' (Witt 1971, 273). Interestingly, Epiphanius also writes that the people of Petra were so in awe of Moses' miracles that 'they made an image of him and mistakenly undertook to worship it' (Epiphanius 1990, 78). All this indicates that the religion of Late Antique Petra was characterized by highly syncretistic combinations based both on the ancient Nabataean religion and on Judaeo-Christian ideas. 
might then associate the structure with al-'Uzza and the pilgrim route from Petra towards Jabal Haroun.

Moreover, an extensive system of barrages and terrace walls on the slopes of the mountain has been documented in the survey. Their dating is uncertain, but judging by the large quantities of Nabataean pottery sherds found particularly in the western foothills of the mountain, the earliest phase of their construction probably dates to the Nabataean period (Lavento et al. 2006, 26). These agricultural installations represent a huge investment of labor, in a semi-arid area which appears to have been almost devoid of human occupation between the Neolithic and the Nabataean period. Furthermore, these extensive installations form a clearly meaningful water conservation and distribution system, which would have been built and maintained under a single management. It is thus possible that the fields may have belonged to an estate administered by a temple at the top of the mountain, dedicated to a goddess of fertility and agriculture. The abovementioned historical tradition that accords Haroun a share of the grain and olive oil may have its roots in antiquity.

Finally, although animal sacrifice is part of orthodox Islam, its roots lie in pre-Islamic religion and its fundamental place in the cult of Haroun finds a parallel in what is known about the cult of al-'Uzza, in which sacrifice is a recurring theme. For example, in the early fifth century St. Nilus the Elder described, in gory ethnographic detail, a pre-dawn camel sacrifice and accompanying meal to the 'Morning Star' ${ }^{\prime 14}$ - unanimously identified as al-'Uzza - by a raiding band of Arabs in the Sinai, while sixth-century Byzantine sources speak of human sacrifices made to her by the Lakhmid kings (Macdonald \& Nehmé 2000, 968). The historical veracity of such sources may be open to question, ${ }^{15}$ but Arab sources also mention al-`Uzzā in connection with blood sacrifices. For example, Hišām Ibn-Muhammad al-Kalbī (d. CE 821/822) suggested in his 'Book of Idols' (Kitāb al-Asnām) that her temple near Mecca was a site of pilgrimage and sacrifice: 'They [the Quraysh] used to journey to her, offer gifts unto her, and seek her favours

14 That al-'Uzza was a planetary deity representing the morning star (Venus) is probable (Healey 2001, 117-8), even if the sources are difficult to interpret (Macdonald \& Nehmé 2000, 967). It is therefore worth noting that prayers sung in early-twentieth-century pilgrimages to Jabal Haroun used astral epithets of Haroun, such as 'Haroun the great star' or 'the father of high planets' (Miettunen 2008, 42-43).

15 The historical accuracy and authorship of Nilus' Narrationes is surrounded by a degree of controversy, but as Caner $(2004,136)$ writes, this does not diminish its value as a description of the beliefs and practices of the fifth-century Near East. 
through sacrifice' (al-Kalbī 1952, 16). Thus the contemporary goat sacrifices, and Burckhardt's note that camels were cooked (and presumably eaten in communal meals) at the weli, may carry an echo from distant times.

\section{Conclusions}

Archaeological approaches to Near Eastern religion, especially of the GrecoRoman period, have been largely dependent on written sources. Written sources are a double-edged sword: they are a great asset to the archaeology of the region, but at the same time their very existence has led to a certain loss of independence for archaeology as a discipline, which is often reduced to illustrating the information derived from written sources. The study of preand protohistoric religion has been much more 'archaeological' in nature, but here a dependence largely on general (comparative) analogy typically only allows the exploration of a frustratingly wide spectrum of interpretative possibilities. The great advantage of the direct historical approach is that it escapes both the tyranny of written sources and the vagueness of general analogy. Although it is itself a form of analogy (and does not, as such, constitute 'scientific proof'), it can enable readings of archaeological material that are strongly supported by empirical evidence and offer completely new insights into ancient religion.

Jabal Haroun is a case in point. The religious significance of the mountain in the Byzantine and Islamic periods is known from written sources, but evidence is now beginning to mount that the mountain was the site of an important sanctuary - probably dedicated to the goddess al-'Uzza/Isis - already in the Nabataean-Roman period. The hypothesis presented here should undoubtedly be considered only as the first step in a comprehensive research programme devoted to a better understanding of the religious, economic and cultural significance of Jabal Haroun throughout the ages, from the Nabataean period until recent times. It is conceivable, for example, that the mountain was sacred to more than one deity (as seems to have been the case at Khirbat at-Tannūr). However, so far the extant historical and archaeological data, coupled with ethnographic information, seem to largely suggest that one of the religious phenomena associated with the rise of Early Christianity in the Near East - the transformation of a pagan cultic place into a sacred, Biblical location - has indeed taken place at Jabal Haroun.

Jabal Haroun, the highest peak in the area, would have easily attracted the attention and imagination of the Petra population throughout history. Although much of the evidence of pre-Christian use of the mountain was 
eradicated (perhaps intentionally) in the Byzantine period, it is conceivable that it was the site of a shrine or even a small temple dedicated to the chief female deity of the Nabataeans. As opposed to the monumental sacral structures in the city centre, built in fashionable Hellenistic-Roman styles, the shrine at Jabal Haroun would have retained a traditional, local character, both in location (exemplifying a 'high place' type) and in architectural appearance. The location was spectacular, even for Petra, and the presence of the natural bedrock fissure at such high altitude, and probably filled with water, would well coincide with Nabataean beliefs and cultic observances. In a wider frame, Jabal Haroun as the main elevation in the direction of the Wadi Araba and as the site of the main 'high place' of the supreme female deity would correspond to the opposite Shara mountains, associated with Dushara ('The Lord of the Shara'), the main male god of the Nabataeans.

Furthermore, the Nabataean holy mountain would most probably have had an economic component, in the form of an associated large-scale, intensive-production agricultural estate. This estate would have continued in the post-annexation period, although certain changes could have taken place. For example, the lack of Roman and Byzantine pottery in the area around the mountain is notable. Perhaps in the Roman period the ownership changed (confiscation of the temple estates) and the mode of production became less intensive. Whether the temple was destroyed in the 363 earthquake or intentionally abandoned is unknown. It seems, however, that at least the traditional association of the mountain with this deity may have survived until Byzantine times.

This is also the period of the second major shift in the cultural history of Jabal Haroun. The persistence of pagan cults at Petra, and the struggle there between Christianity and traditional cults, is well attested in the fourth century, even if only through certain apocryphal sources. According to one such story, a Syrian monk called Barsauma encountered pagan temples at Petra as late as around 419-23; when he urged the citizens to abandon their idols, they closed the city gates against him (Nau 1927, 186-7). It is thus evident that the process of Christianization of locations with pagan associations would have been much in the interest of the ascending religious elite. Already in the fourth century the association of the Petra area with the Israelite wanderings in the desert was well established, and the assimilation of the Biblical Mount Hor to the highest peak in the area would be most natural and imaginative. A further 'bonus' in the process of eradicating the cult of the female deity would be her replacement with a well-known Biblical male figure - that of Aaron. Possibly even the bedrock fissure at the plateau 
may have achieved a new meaning: that of the rock which upon Moses' intervention miraculously produced water (cf. the account by Eusebius, mentioned earlier). A natural end-result of this process could have been the foundation of the monastery for pilgrimages to the mountain.

Other examples of the Christianization of pagan places and edifices at Petra are easily forthcoming. The monumental Urn Tomb in the centre of the 'royal' necropolis carved in the face of the al-Khubta cliffs, the largest in Petra, was converted into a church in 447 (Brünnow \& Domaszewski 1909, 345). Another Nabataean monumental tomb known as Ed-Deir ('the Monastery'), the area of which in the Nabataean period appears to have been used as a high place type of ritual place (Healey 2001,47-50), seems to have been adopted to Christian use (as indicated by the inscriptions published in Sartre 1993, 109-10), possibly with the laura-type monastic cells located nearby. Similarly, a little to the north of Petra, the site of Khirbet edh-Dharih features a Nabataean temple that was later turned into a Christian church (Villeneuve \& al-Muheisen 2000).

Despite the lack of clear historical references, the monastic establishment at Jabal Haroun must have been quite successful in terms of longevity and attraction for pilgrims, surviving well into the Islamic period. Even after Christian monasticism at Jabal Haroun came to an end, the revering of the Prophet Haroun continued. But the curious mixture of folklore related to Haroun suggests that alongside with 'official' Christian and Islamic doctrine a strand of much older religious observance continued, and that some of the most ancient elements of Petra religion may not have been entirely forgotten even in recent times.

Bibliography

Arjava, Antti \& Matias Buchholz \& Traianos Gagos (eds) 2007 The Petra Papyri III. Amman: American Center of Oriental Research.

Bignasca, A. \& N. Desse-Berset \& R. Fellmann Brogli \& R. Glutz \& S. Karg \& D. Keller \& B. Kolb \& Ch. Kramar \& M. Peter \& S. G. Schmid \& Ch. Schneider \& R. A. Stucky \& J. Studer \& I. Zanoni

1996 Petra. Ez Zantur I. Ergebnisse des Schweizerisch-Liechtensteinischen Ausgrabungen 1988-1992. Mainz: von Zabern. 


\section{Binford, Lewis}

1967 Smudge-pits and Hide-smoking: The Use of Analogy in Archaeological Reasoning. - American Antiquity 32, 1-12.

Brünnow R. \& A. von Domaszewski

1909 Die Provincia Arabia III. Strassburg: Trübner.

\section{Burckhardt, John Lewis}

2007 (1822) Travels in Syria and the Holy Land. Charleston, USA: BiblioBazaar.

\section{Caner, Daniel}

2004 Sinai Pilgrimage and Ascetic Romance: Pseudo-Nilus' Narrationes in Context. - Linda Ellis \& Frank Kidner (eds), Travel, Communication, and Geography in Late Antiquity: Sacred and Profane, 135-47. Ashgate: Burlington.

\section{Crawford, Gregory}

2003 Petra and the Nabataeans. A Bibliography. (ATLA Bibliography Series, No. 49.) Lanham: MD and Oxford.

\section{Crawford, Stewart}

1930 The Attitude of the Present Day Arab to the Shrine of 'Mt. Hor'. - George Livingston Robinson (ed.), The Sarcophagus of an Ancient Civilization, 285-300. New York: Macmillan.

Cunningham, Jeremy

2003 Transcending the 'Obnoxious Spectator': A Case for Processual Pluralism in Ethnoarchaeology. - Journal of Anthropological Archaeology $22(4), 389-410$.

\section{Di Segni, Leah}

2007 On the Development of Christian Cult Sites on Tombs of the Second Temple Period. - ARAM Periodical 19, 381-401.

\section{Donner, Herbert}

1995 Isis in Petra. Leipzig: Ägyptologisches Institut/Ägyptisches museum.

\section{El-Khouri, Lamia}

2007 Nabataean Pilgrimage as Seen through Their Archaeological Remains. - ARAM Periodical 19, 325-40.

\section{Epiphanius Constantiensis}

1990 The Panarion of St. Epiphanius, Bishop of Salamis. Translated by Philip R. Amidon. New York: Oxford University Press. 


\section{Eusebius of Caesarea}

2005 Onomasticon. The Place Names of Divine Scripture. [Including the Latin Edition of Jerome.] Translated into English and with Topographical Commentary by R. Steven Notley \& Ze'ev Safrai. Leiden: Brill.

\section{Fahlander, Fredrik}

2004 Archaeology and Anthropology - Brothers in Arms? On Analogies in 21st-century Archaeology. - Fredrik Fahlander \& Terje Oestigaard, Material Culture and Other Things, 185-211. Gothenburg: University of Gothenburg.

Fiema, Zbigniew $\mathrm{T}$.

2002 Late-Antique Petra and its Hinterland: Recent Research and New Interpretations. - Journal of Roman Archaeology 49, 191-252.

2003 Roman Petra (A.D. 106-363). A Neglected Subject. - Zeitschrift des Deutschen Palästina-Vereins 119/1, 38-58.

2008 The Concluding Remarks. - Zbigniew T. Fiema \& Jaakko Frösén 2008, Petra - the Mountain of Aaron. Vol. I. The Church and the Chapel, 425-41. Helsinki: Societas Scientiarum Fennica.

Fiema, Zbigniew, T. \& Chrysanthos Kanellopoulos \& Tomasz Waliszewski \& Robert Schick

2001 The Petra Church. (ACOR Publication no 3.) Amman, Jordan: American Centre of Oriental Research.

Fiema, Zbigniew T. \& Jaakko Frösén (eds)

2008 Petra-the Mountain of Aaron. Vol. I. The Church and the Chapel. Helsinki: Societas Scientiarum Fennica.

Frösén, Jaakko

2001 The First Five Years of the Petra Papyri. - I. Andorlini \& G. Bastianini \& M. Manfredi \& G. Menci (eds), Atti del XXII Congresso Internazionale di Papirologia, Firenze, 23-29 Agosto 1998, 487-93. Firenze: Istituto Papirologico 'G. Vitelli'.

2004 Archaeological Information from the Petra Papyri. - F. el Krayesh (ed.), Studies in the History and Archaeology of Jordan VIII, 141-4. Amman: Department of Antiquities of Jordan.

Frösén, Jaakko \& Zbigniew T. Fiema

1994 The Petra Papyri. - ACOR Newsletter 6 (2), 1-3.

Frösén, Jaakko \& Zbigniew T. Fiema (eds)

2002 Petra-A City Forgotten and Rediscovered. Volume associated with the exhibition organized by the Amos Anderson Museum, Helsinki, Finland. (Amos Anderson Museum Publications no. 40.) Helsinki: Amos Anderson Museum. 
Frösén, Jaakko \& Antti Arjava \& Marjo Lehtinen (eds)

2002 The Petra Papyri I. Amman: American Center of Oriental Research.

Frösén, Jaakko \& Päivi Miettunen

2008 Aaron in Religious Literature, Myth, and Legend. - Zbigniew T. Fiema \& Jaakko Frösén (eds), Petra - the Mountain of Aaron. Vol. I. The Church and the Chapel, 5-25. Helsinki: Societas Scientiarum Fennica.

Frösén, Jaakko \& Zbigniew T. Fiema \& Henrik Haggrén \& Katri Koistinen \& Mika Lavento \& Glen L. Peterman

1998 The Finnish Jabal Hārūn Project Report on the 1997 Season. - Annual of the Department of Antiquities of Jordan 42, 483-502.

Frösén, Jaakko \& Zbigniew T. Fiema \& Mika Lavento \& Katri Koistinen \& Richard Holmgren \& Yvonne Gerber

2000 The 1999 Finnish Jabal Hārūn Project: a Preliminary Report. - Annual of the Department of Antiquities of Jordan 44, 395-424.

\section{Fulcher of Chartes}

1913 Fulcheri Carnotensis historia Hierosolymitana (1095-1127). Edited by Heinrich Hagenmeyer. Heidelberg: C. Winter.

\section{Gagos, Traianos \& Jaakko Frösén}

1998 Petra Papyri. - Annual of the Department of Antiquities of Jordan XLII, 473-481.

Hackl, Ursula \& Hanna Jenni \& Christoph Schneider

2003 Quellen zur Geschichte der Nabatäer. (Novum Testamentum et Orbis Antiquus 51.) Freiburg \& Göttinge: Universitätsverlag Freiburg Schweiz, Vandenhoeck \& Ruprecht Göttingen.

Hammond, Phillip C.

1996 The Temple of the Winged Lions, Petra, Jordan, 1974-1990. Fountain Hills (AZ): Petra Publishers.

Healey, John F.

2001 The Religion of the Nabataeans: a Conspectus. Boston: Brill.

Hirschfeld, Yizhar

1992 The Judean Desert Monasteries in the Byzantine Period. New Haven and London: Yale University Press.

Josephus (Flavius Josephus)

1991 Jewish Antiquities Books I-IV. Ed. and transl. by H. St. J. Thackeray. (The Loeb Classical Library.) Cambridge, Mass., London: Harvard University Press and W. Heinemann. 


\section{Joukowsky, Martha, S.}

1998 Petra Great Temple, volume 1: Brown University Excavations 1993-1997. With contributions by Christian Augé, Deirdre G. Barrett, Joseph J. Basile, Jean Blackburn, Leigh-Ann Bedal, Donna J. D'Agostino, Sara G. Karz, Elizabeth E. Payne, Thomas R. Paradise, Erika L. Schluntz, Monica L. Sylvester, Stephen V. Tracy, Loa P. Traxler, Terry Tullis, Peter Warnock, and Paul C. Zimmerman. Providence (RI): Petra Exploration Fund.

\section{al-Kalbī, Hišām Ibn-Muhammad}

1952 The Book of Idols: Being a Translation from the Arabic of the Kitāb al-asnam by Hishāam ibn-al-Kalbī. Translated with introduction and notes by Nabih Amin Faris. Princeton (NJ): Princeton University Press.

Lavento, Mika \& Esa Hertell \& Paula Kouki \& Annika Mukkala \& Sarianna Silvonen \& Heini Ynnilä \& Henrik Haggrén \& Hanne Junnilainen \& Anna Erving

2006 The Finnish Jabal Haroun Project Survey: Preliminary Results from Six Seasons of Archaeological Fieldwork in Jordan. - Proceedings of the Finnish Institute in the Middle East 1/2006.

\section{Leontios of Damascus}

1991 Vita di Santo Stefano Sabaita. Edited and translated by Bartolomeo Pirone. Jerusalem: The Franciscan Centre of Christian Oriental Studies.

\section{Lindner, Manfred}

1997 Petra und das Königreich der Nabatäer: Lebensraum, Geschichte und Kultur eines arabischen Volkes der Antike. München: Delp.

2003 Von Isis zu Aaron. Archäologische Wallfahrt zum Jebel Harun. - Über Petra hinaus. Archäologische Erkundungen im südlichen Jordanien, 177-204. Rahden: Verlag Marie Leidorf.

\section{Lyman, R. L. \& M. J. O'Brien}

2001 The Direct Historical Approach, Analogical Reasoning, and Theory in Americanist Archaeology. - Journal of Archaeological Method and Theory 8 (4), 303-42.

\section{Macdonald, M. C. A. \& Laila Nehmé}

2000 Al-Uzzā. - The Encyclopaedia of Islam, vol. X, 967-86. Leiden: Brill.

\section{Magister Thetmar}

1983 Magister Thetmarus, Iter ad Terram Sanctam - Il Maestro Tetmaro, Viaggio in Terra Santa. - Sabino De Sandoli (ed.), Itinera Hierosolymitana Crucesignatorum, saec. XII-XIII: textus Latini cum versione Italica, vol.3, 251-95. Transl. T. Tobler. (Pubblicazioni dello Studium Biblicum 
Franciscanum, Collectio maior 24:3.) Jerusalem: Franciscan Printing Press.

\section{al-Mas' ū $\mathbf{d} \bar{i}$, Abū al-Hasan 'Alī}

1894 Kitāb al-Tanbīh wa-al-Ishrāf. Edited by M. J. de Goeje. Leiden: Brill.

\section{McKenzie, J. \& A. Reyes \& S. Gibson}

2002 Khirbat at-Tannūr in the ASOR Nelson Glueck Archive and the Reconstruction of the Temple. - Annual of the Department of Antiquities of Jordan 46, 451-76.

\section{Miettunen, Päivi}

2004 Darb Al-Nabi Harun. The Veneration of the Prophet Harun in the Petra Region - Tradition and Change 1812-2003. Unpublished Master's Thesis at the Department of Semitic Studies. Helsinki: University of Helsinki.

2008 Jabal Haroun: History, Past Explorations, Monuments, and Pilgrimages. - Zbigniew T. Fiema \& Jaakko Frösén (eds), Petra - the Mountain of Aaron. Vol. I. The Church and the Chapel, 27-49. Helsinki: Societas Scientiarum Fennica.

\section{Mikkola, Erko \& Antti Lahelma \& Zbigniew T. Fiema \& Richard Holm-} gren

2008 The Church and the Chapel: Analysis and Phasing. - Zbigniew T. Fiema \& Jaakko Frösén (eds), Petra - the Mountain of Aaron. Vol. I. The Church and the Chapel, 83-161. Helsinki: Societas Scientiarum Fennica.

\section{Musil, Alois}

1907 Arabia Petraea vol. II, Edom. Kaiserliche Akademie der Wissenschaften. Wien: Alfred Hödler.

1928 The Manners and Customs of the Rwala Bedouins. New York: American Geographical Society.

Nau, F.

1927 Deux épisodes de l'histoire juive suis Théodose II (423 et 438) d'apres la vie de Barsauma le Syrien. - Revue des Études Juives 83, 184-206.

\section{Orme, Bryony}

1974 Twentieth-Century Prehistorians and the Idea of Ethnographic Parallels. - Man, New Series 9 (2), 199-212.

\section{Parr, Peter}

1962 A Nabataean Sanctuary Near Petra: A Preliminary Notice. - Annual of the Department of Antiquities of Jordan 6/7, 21-3. 


\section{Peterman, Glen L. \& Robert Schick}

1996 The Monastery of Saint Aaron. - Annual of the Department of Antiquities of Jordan 40, 473-80.

\section{Robinson, George L.}

1908 The High-Places of Petra. - The Biblical World XXXI (1), 8-21.

\section{Ruben, Isabelle (ed.)}

2003 The Petra Siq. Nabataean Hydrology Uncovered. With the contributions by Ueli Bellwald, Ma'an al-Huneidi, Adnan Salihi, Daniel Keller, Rajah Naser, Dawud al-Eisawi. Amman: Petra National Trust.

\section{al-Salameen, Zeyad \& Hani al-Falahat}

2007 Jabal Haroun During the Islamic Period: A Study in the Light of Newly Discovered Inscriptions. - Arabian Archaeology and Epigraphy $18,258-64$.

\section{Sartre, Maurice}

1993 Pétra et la Nabatène méridionale du Wadi al-Hasa au Golfe de 'Aqaba. (Inscriptions de la Jordanie 4.) Paris: Geuthner.

\section{Schmid, Stephan G.}

2001 The Nabataeans: Travellers between Lifestyles. - B. R. Adams MacDonald \& P. Bienkowski (eds), The Archaeology of Jordan, 367-426. Sheffield: Sheffield Academic Press.

\section{Schmid, G. Stephan \& Bernhard Kolb}

2000 Petra ez Zantur II. Teil 1. Stephan G. Schmid, Die Feinkeramik der Nabatäer. Typologie, Chronologie und kulturhistorische Hintergründe. Teil 2. Bernhard Kolb, Die spätantiken Wohnbauten von ez Zantur in Petra und der Wohnhausbau in Palästina vom 4.-6. Jh. n. Ch. Mainz: von Zabern.

\section{Stahl, Ann}

1994 Change and Continuity in the Banda Area, Ghana: The Direct Historical Approach. - Journal of Field Archaeology 21 (2), 181-203.

\section{Steward, Julian}

1942 The Direct Historical Approach in Archaeology. - American Antiquity 7 (4), 337-43.

\section{Trigger, Bruce}

1989 A History of Archaeological Thought. Cambridge: Cambridge University Press.

1995 Expanding Middle-Range Theory. - Antiquity 69 (264), 449-58. 


\section{Walmsley, Alan}

2001 Fatimid, Ayyubid and Mamluk Jordan and the Crusader Interlude. - B. R. Adams MacDonald \& P. Bienkowski (eds), The Archaeology of Jordan, 515-59. Sheffield: Sheffield Academic Press.

\section{Wiegand, Theodor}

1920 Sinai. (Wissenschaftlische Veröffentlichungen des Deutsch-Türkischen Denkmalschutz-Kommandos. Heft 1.) Berlin: W. de Gruyter.

Wild, Robert A.

1981 Water in the cultic worship of Isis and Sarapis. Leiden: Brill.

\section{Villeneuve, François \& Zeidoun al-Muheisen}

2000 Nouvelles recherches à Khirbet edh-Dharih (Jordanie du Sud, 19961999). - Comptes Rendus de l'Académie des Inscriptions \& Belles-Lettres 2000 (4), 1525-71.

Witt, R. E.

1971 Isis in the Graeco-Roman World. London: Thames \& Hudson.

\section{Wylie, Alison}

1985 The Reaction against Analogy. - M. B. Schiffer (ed.) Advances in Archaeological Method and Theory 8, 63-111. San Diego (CA): Academic Press.

\section{Zayadine, Fawzi}

1985 Caravan Routes between Egypt and Nabataea and the Voyage of Sul$\tan$ Baibars to Petra in 1276. - A. Hadidi (ed.) Studies in the History and Archaeology of Jordan II, 159-174. Amman: Department of Antiquities of Jordan. 